\title{
Baggage Reclaim: Some thoughts on feminism and painting
}

Rebecca Fortnum, Royal College of Art

\begin{abstract}
This article calls for a reappraisal of the feminist discussion around painting in relation to contemporary practices by women, suggesting that all painting by women has something to offer the feminist critical thought. Playfully using Judy Chicago's reflections and strategies as a frame, the article explores how contemporary painters have engaged with the histories and communities of women to form new models of scholarship and practice. It examines the projects of painters Melissa Gordon, Nadia Hebson and the Obscure Secure group (Jacqueline Utley, Hayley Field and Claudia Böse) whose artwork forms a 'live' response to the legacy of little known and undervalued women artists. The article concludes by examining the notion of the painterly gesture and develops a feminist context in which to examine the materiality and processes of painting, with reference to the perspectives of Dana Schutz and Jutta Koether among others. It suggests Helen Molesworth's historically defined quality of ambivalence can be seen resurfacing as a critical position within contemporary painting by women.
\end{abstract}

\section{Keywords}

feminism

painting

Judy Chicago

gesture

ambivalence 
collective

art history

In Through the Flower, Judy Chicago explains her alienation from the practice of painting:

I had painted these large, technically formidable paintings and, although they were beautiful, they still did not speak the language of my real self....I felt that I would have to give up the painting methods that I knew... I wanted to bring my art and my feminism together and I did not see how to do it with the art making methods I had. (Chicago [1975] 2006: 103)

Later on in her account of her 'struggle as a woman artist' she attempts to reconcile her artworks where there is 'clear content' and her paintings that (in her view) 'possess layers of meaning', questioning 'what did [my installation] "Menstruation Bathroom" have to do with my abstract work?' (Chicago [1975] 2006: 137). Ultimately, however, she makes a decided return to painting: 'I wanted to wed my skills to my real ideas... [I realised] I did not have to abandon my art making process' (Chicago [1975] 2006: 138). Although a contemporary audience might find Chicago's apparent lack of nuance in her aesthetic account amusing, the difficulty of asking painting to articulate on behalf of the women's movement (or indeed any political movement) still casts a long shadow over painting by feminists. Indeed, it could be said that Chicago's 'full circle', away from painting and back again, is only just being completed by feminist artists, and it has been some time in the making. However, it is 
surely impossible to explore the notion of commitment in art without reflecting on the importance and impact of feminism. Of course, as various studies continue to affirm, gender inequality in the visual arts is still in place, and while the challenges made by feminist theory to accepted value systems within the structures of art have been influential in many disciplines, they have perhaps made less headway when it comes to the status of painting practices by women. ${ }^{1}$ Yet women appear to be painting today in unprecedented numbers, often without much recognition, leading one to believe that there is still something important at stake for women artists within contemporary painting. ${ }^{3}$

For feminists, painting carries baggage. Subsequent to Chicago's account of the 1970s feminist interventions into art practices, a persistent belief that some mediums, like painting, should be left 'in quarantine' by artists engaged in making critical art, was reinforced by the exclusively masculine New Spirit in Painting (RA London, 1981). As the 1990s progressed, direct and overt 'calls to arm' produced by politically committed artists were replaced by less overt practices. The New York, Los Angeles and London Bad Girls exhibitions of 1993 and 1994 were critically savaged by feminist and conservative critics alike and finding a practitioner who was happy to identify as a feminist artist was becoming more difficult. If feminist art was fugitive then feminist painting was even more so, with some artists only adopting the label temporarily or partially. Sue Williams, whose canvases relayed abject tales of domestic abuse and misogyny and were included in Bad Girls, explained her 'complete about-face' to the New York Times in 2001, 
I got really dissed by critics. 'Whiny, self-indulgent, victim art,' they said. I felt misunderstood. I thought of my art as funny and as social statements. I didn't see it as cathartic. I wasn't making up anything grosser than what had really happened to me. But after a while I got tired of the politics and the in-fighting. I wanted to play around with paint. I got interested in just doodling, and my work went through a really ugly patch for a while when I learned how to use oil paint. (Kimmelman 2001: n.p.)

It may be worth analysing Williams' account of the change within her painting practice in order to explore the factors militating against an understanding of painting's potential to contribute to feminist thought. In the first instance there is the issue of reception. It is clear Williams did not feel sustained by her earlier work's critical reception. There was no - or not enough - understanding of her aims or acceptance of their (feminist) worth; sadly, no one got her jokes. The artist's desire for a reading of the work as an active, feminist reflection on the society's misogyny ('social statements') went, in the main, unrealized, possibly because it was complicated by her simultaneous reference to her painting's documentation of 'what happened to me'. The critical reception did not seem able to accommodate the work as both experience and commentary and the painting as unmediated autobiography crowded out other readings of the work. This, of course, restaged art history's conflation of paintings with the painter, a move most often proven to be detrimental to the critical standing of women artists. Further, this lack of serious critical attention in turn led Williams, like Chicago before her, to pit social comment against an exploration of the materiality and processes of paint. In doing this Williams appears to be internalizing an anti-intellectualism that absents her work's content. While it is 
hard to believe she fully means this, 'tired of politics and infighting' Williams appears to take refuge as an outsider - the painting becoming the vacuous doodling of an infant at (joyous) play, a caricature familiar to all. A more recent example of this view comes from Jenny Saville, one of the very few contemporary painters to receive a range of feminist critical attention, who also contrasts painting to what she terms an 'algorithmic' (or conceptual) approach to making, saying in an interview in 2012, 'There's something primal about [painting]. It's innate, the need to make marks. That's why, when you're a child, you scribble' (Cooke 2012: n.p.). Although sixteen years younger than Williams, Saville has also found it necessary to articulate a division between the processes of painting and rational thought, perhaps in an attempt to not over-determine her own practice, a risk for any living artist in the critical eye. That this unhelpful polarization of thinking and feeling is not (and never was) the proper terms of the debate around critical painting must be remembered or feminist painters will continue to face an unhappy choice between cause or discipline, each appearing to require mutually exclusive forms of commitment.

\section{Where to commit?}

In Reading Art, Reading Irigaray: The Politics of Art by Women, Hilary Robinson points out the lack of feminist scholarship on contemporary painting:

If Painting (as capitalised act) is left undisrupted by feminist theorising in the culture, then not only will feminists who are painting remain marginal, their strategies reduced to ones of choice of medium, but also, crucially, any feminist 
interventions into the practices of painting may well remain broadly illegible, even to other feminists. (2006: 111)

In recent years the dearth that Robinson alludes to has been accompanied by a sense of the strength of women on the scene of contemporary painting, as Fran Lloyd optimistically wrote in 2000 , 'Painting is now visibly established as an important and vital area of feminist activity' (Lloyd 2000: 37), and Rosemary Betterton's stated aim in her book Unframed, the Practices and Politics of Women's Contemporary Painting from 2004 was to 'move debates beyond a sterile set of opposition between abstractions and realism, feminist or non feminist genres, traditional or new media, modernist or postmodernist painting' (Betterton 2004: 2). However, the continued absence of feminist critical attention for painting, when coupled with the abundance of contemporary painting by women (that only occasionally achieves the critical status and rarely the commercial value of painting by their male counterparts) would seem to suggest that the terms of this enquiry have still not taken hold. One problem might be a perception of a mismatch between feminism and painting as forms of enquiry. If feminism is about collective endeavour, then how might painting act beyond the actions of an individual to engage with a community of women and their histories? And if, as the painter Mamma Andersson suggests, artistic creation is 'poetry...the opposite of political and pragmatic thinking' (Hawkey 2007: n.p.), how can painting speak to, for and about feminism?

In her important 1992 essay 'Painting, feminism, history’, Griselda Pollock states, 
[Women] want to paint, a desire which is as much about wanting the right to enjoy being the body of the painter in the studio - the creative self in the private domain - as it is about wanting to express individualistically the none the less collective experiences of women. (1992: 140)

She goes on to note the gendered nature of this individual authorship:

Painting is privileged in modernist discourse as the most ambitious and significant art because of its combination of gesture and trace, which secure by metonymy the presence of the artist. These inscribe a subjectivity whose value is, by visual inference and cultural naming, masculinity. (Pollock 1992: 142)

Nowhere is this more explicit than in Abstract Expressionism's painterly gesture, a conflation of feeling and meaning that connotes an expression of 'radical individuality' (Molesworth 2007: 437) or as Linda Nochlin puts it, when writing about the painter Joan Mitchell,

The gesture seems to constitute a direct link to the psyche of the artist without even an apple or a jug to mediate the emotional velocity of the feeling in question. (Nochlin 2002: 50)

Although Pollock's essay champions the right of women to use paint (as much as any other media) she is clear that 'Feminisms and the discourses of art are locked into a profound contradiction at the site of the expression of the creative self' (Pollock 1992: 145). Although in many ways this theoretical analysis was and is emancipating, 
articulating the very real difficulties in becoming or recognizing female painters, when applied as a yardstick to the work of living women artists there is the potential to create a division of allegiances, allowing women artists to be critiqued as 'good' or 'bad' feminists, often leading artists to make public disavowals of feminism in favour of art.

Today, however, the characterization of the painter as a solitary 'master' figure is hard to sustain. As Avigail Moss asks,

In a time when some painters function as creative directors running studios, while other painters incorporate painting as only one part of their practice....how should we distinguish the day-to-day work of the painter from the work of all artists? ( Moss 2011: 20)

The expansion of painting's modes of production and dissemination has necessarily heralded a corresponding diverse critical evaluation of the discipline. For feminism this extension of painting as a field of enquiry rather than a medium-specific discourse is useful in navigating Betterton's 'sterile set of oppositions' (Betterton 2004: 2). Indeed it might not be too farfetched to conjure back into use a model already available in Carol Hanisch's famous 1976 essay, 'The personal is political', written as a response to criticism of the group mechanism of 'consciousness raising' as an action that was not truly political, 'One of the first things we discover in these groups is that personal problems are political problems. There are no personal solutions at this time. There is only collective action for a collective solution' (Hanisch 1969: n.p.), and re-iterated within an art context by Martha Rosler, 'Is the 
personal political? No, if the attention narrows to the privileged tinkering with or attention to one's solely private sphere, divorced from any collective struggle' (Elwes 1996: n.p.). Hanisch reflects on her experience of feminist activism:

I think we who work full-time in the movement tend to become very narrow. What is happening now is that when non-movement women disagree with us, we assume it's because they are 'apolitical,' not because there might be something wrong with our thinking.... What I am trying to say is that there are things in the consciousness of 'apolitical' women (I find them very political) that are as valid as any political consciousness we think we have. (Hanisch 1969: n.p.)

Her stress on the importance of feminism as critical, collective and inclusive leads her to acknowledge articulations that not only are undervalued in society at large but are also unruly, ambivalent or seemingly marginal to the feminist project. Her refusal to submit to thinking that places women 'in' or 'outside' the Movement gives rise to a shift that allows feminism to seek value in all women's thinking and by extension perhaps, art production. In the terrain of contemporary art practice, I would like to suggest that now might be the time to start claiming the practices by contemporary women painters - all of them - for feminist critical attention. This approach could acknowledge submerged, complicated and contradictory forms of commentary and expression that might be put to use articulating a resistance to dominant cultural values and position painting as an active space for thought and communication, rather than as a passive repository of feeling. By moving discussion away from Chicago's need for interpretative purity the possibilities of a medium, arguably at its best when it 
engenders complex layers of interpretation, becomes open to feminist critical insights. ${ }^{4}$ A commitment to an inclusive community also suggests a confidence in the value of women's cultural production, as Anne-Marie Sauzeau-Boetti suggested in 1979 ,

....when a woman artist lives profoundly as a woman in her profession and strongly enough in her mastery of the means she is managing, it's my belief that a gradual differentiation from this 'father' art occurs. (Sauzeau-Boetti [1979] 2015: 229)

Might 'living profoundly as a woman' in the profession of painting lead to a shift in the critical value systems of the discipline? In the first instance this may mean that the painter does indeed move beyond her 'solely private sphere' to forge dialogue with other women, in order to engage with the 'collective struggle' of feminism.

\section{What would Judy do? Strategies to form communities and histories}

The narrative of Through the Flower ([1975] 2006) is formed by Chicago's encounters with other artists, particularly women, and it is clear that these are crucial to her development as an artist. From Anais Nin's supportive introduction and her intense relationship with her collaborator and 'mother figure', Miriam Shapiro, to the students who she encourages, cajoles and occasionally dominates, her relationships with other women forms, as much as informs, her thinking. Chicago's peers do not only act as her supporters, audience and critics but also, crucially, she sees them as 
actively changing how her work will be seen and evaluated. She triumphantly writes on the gallery walls housing her The Great Ladies exhibition (1972), 'My paintings can only be fully understood in this new context we have made' (Chicago [1975] 2006: 204), that is, the paintings, rather than acting autonomously, are contingent on a context that the artist activates, if not actually authors. Chicago views her paintings as dependent on an engaged and informed feminist viewer to fulfil the work's promise, collectively building the tools with which to make the work's meaning, as did the women artists of New York's AIR Gallery's that not only

initiate[d] new networks of exhibition and discussion - new circuits of information - but ... also sought to retain control of 'its intellectual capital and its creative games' rather than allowing the market to appropriate them, which would risk draining the work of its feminist content. (Joselit 2015: 176)

This strategy can be seen operating today in painter Melissa Gordon's project, 'a conversation to know if there is a conversation to be had', a series of meetings for female artists held in 2010-11 in New York, Amsterdam and Berlin, and their resulting publications or Nadia Hebson's Moda WK, an expanded painting exhibition in Newcastle (2013) that explored 'the creative significance of female friendship' in a response to the work of modernist artist Winnifred Knights with artists Titania Seidl and Holly Antrum. Another project, Obscure Secure, developed by the painters Claudia Böse, Hayley Field and Jacqueline Utley after they met to discuss their shared interest in the processes of painting, has evolved into a collective, ongoing research process, leading to exhibitions and a number of public discussions and lectures. In meeting to discuss their individual interests these artists have become 
aware of the points of difference and confluence, proceeding (in their own words) 'carefully and deeply’ (Böse 2014: n.p.), respectful of their individual histories and sensibilities and yet also developing the trust to provide critical challenges to each other's thinking. Their collaboration has been formed to establish mutual support that they see as running contrary to art world hierarchies and competition, allowing them to work together for a 'shared purpose' and 'neutralising envy' (Böse et al. 2016: n.p.) and crucially locating value outside the dominant and excluding commercial structures.

Chicago uses her knowledge of historical precedent to establish a model of excavation in order to reach what she sees as her own authentic, yet submerged, female voice. In her aim to bring her art and feminism together and with her typical proactiveness, she sets about a self-education in the history of women's painting. Presumably drawing on Linda Nochlin's work, Chicago turns to historical precedent in her quest to understand how she might paint as a feminist, and this work eventually provides the foundations for her most famous work. It is important for her that feminism allows her to lay a claim on women's cultural production and make connections to her own sensibility, as well as use history to better understand the obstacles in the race. Her path back to painting is thus studded with delighted revelations as she discovers an historical roll call of works by women. It is interesting to note a very different painter, the young Vija Celmins, Chicago's contemporary at graduate school in UCLA, also searching out a female lineage,

As a young woman artist... I used to think I could paint like Grace Hartigan. Or once I went to visit Georgia O'Keefe, and she wasn't home..... You know at 
that time there were very few women models. There were mostly men painters. I had a certain amount of feeling for making things, and I had the ambition to want to make some terrific paintings. For the most part I felt quite isolated, and think I spent a lot of time alone painting in the studio until I had my first show. (Bui 2010: n.p.)

The need to find role models, as well as peers, was (and still is) a crucial part of any artist's development, and for women, often isolated, the desire to forge a relationship with other women is crucial in giving them 'permission' to practise. Thus, feminist art scholarship that not only dwells on magnificent exceptions but also reflects on communities of influence becomes crucial. For example, Jenny Saville's critical attention mostly fails to pass the Bechdel test; she is routinely discussed in relation to the older artist Lucian Freud, yet one might as easily relate her to closer peers, the Scottish artists Gwen Hardie, Alison Watt or Anne Morrison..$^{5}$ A better known context and more astute comparative analysis may have helped the young Saville counter David Sylvester's comment to her, 'I always thought women couldn't be painters....I don't know [why]. That's just the way it has always been. That's how it is' (Cooke 2012: n.p.).

In her article 'A motivated history', the art historian Sue Tate observes 'a fascinating pattern of work by contemporary women artists, responding to, or in dialogue with, women artists or designers of previous generations; ... opening up the possibility of a different future' (Tate 2013: 85), and goes on to discuss, among other examples, a painting by Paulina Olowska made in response to seeing and researching the work of pop artist Pauline Boty. In contemporary practices by women, this historical homage 
(femage?) has indeed become an enthralling strategy, appearing to operate rather differently from the models Harold Bloom describes, where swashbuckling poets address their anxiety towards influential forebears by 'wrestl[ing] their strong precursors, even to the death' ([1973] 1997: 5). Perhaps because the history of women's art is still so fragile, these artists often see themselves as informed and creative interpreters in a methodology akin to collaboration and dutiful scholarship, rather than aiming to make 'history by misreading one another, so as to clear imaginative space for themselves' (Bloom [1973] 1997: 5). An integral part of the Obscure Secure's 'deceptively modest project' (Spalding 2014: 3) - indeed the thinking behind its name - is the undertaking of an archival dig to select works by women for exhibition from the art collection secured for posterity by the Ipswich Borough Council for the East of England, but obscured from sight in their storage facilities. These women artists, for the most part currently unknown, often after bright careers, become the silent partners in their collaboration. Their archival discoveries become both emblematic of a lost history, neglected oeuvres and lives of early twentieth-century women artists denied their legacy of influence, and yet are also brought to new life and relevancy, being drawn into a contemporary conversation with new paintings by the three artists inspired by them. The project delights in its insistence on the provincial and unremarkable both in subject matter and site, as the Obscure Secure exhibition temporarily restores the work to the walls of the municipal art gallery of Ipswich's Christchurch Mansion. These paintings emerge from the period when women were first properly admitted to art schools and, with one exception (Prunella Clough, 1919-99), their fate is to be categorized as quintessentially English and quite possibly 'feminine'. Looking at their choices, works dating from 1920-73, I am reminded of Virginia Woolf's dinner at the 
'Oxbridge' women's college in A Room of One's Own (1929) where the 'amenities will have to wait' and they are served the pudding of 'uncharitable' prunes; there are no wild flourishes or overreaching in these small works. However, selecting and displaying these pieces allows us to see them afresh and their juxtaposition with contemporary work suggests that we have permission to draw on our current painting sensibilities to form new appraisals of the work. As Frances Spalding commented,

All these pictures had a voice, a sensibility, and in some cases a sensuality, which, cumulatively, created a visual dance, made even more exuberant by the break with conventional hanging, for these exhibits rose up and across the wall in an order that seemed open, possibly haphazard. Certainly it was an arrangement in which any notion of a hierarchy of importance had been discarded. (Böse et al. 2015: n.p.)

In this context, then, their unshowy qualities become a virtue and they shine with a quiet intensity (as do the new paintings placed with them). In presenting their own work among these earlier paintings by forgotten women painters the Obscure Secure artists deliberately, and somewhat perversely, align themselves with the historical footnote - no 'great ladies' here - but the strategy is effective in drawing attention to the way women are historically positioned, while simultaneously finding a freedom in their marginal status. The activity of the painter on the surface of the canvas becomes the baton (or paintbrush) being passed on to the next generation of women who in turn rescue the earlier artists (temporarily) from the archive. The implicit acknowledgement - that most artistic production is destined for obsolescence and 
obscurity - is not mourned, but rather pleasure is sought in the brief halt in the work's trajectory from production to destruction.

More recently their shared interest in the gesture that both asserts and hesitates has centred around a more in-depth response to the work of Mary Potter (1900-81), an English painter whose work, although listed in the Ipswich archive, had gone missing - sent out on loan never to return. As with their Ipswich project their interest in her is part biographical; she achieved success in her lifetime, with shows at the Tate, Serpentine and Whitechapel Galleries, as well as being awarded an OBE, but is now chiefly 'famous for being in a famous man's back yard' (Benjamin Britten built her a studio in the garden of his Red House) and thus provides a classic case study for the disappearance of women from art history. The subjects she chose, views from windows, interiors, still life and domestic subjects, also appeal to the artists' interest in the subtlety and poetic of the domestic. In the main, however, they are interested in the sensations Potter's paintings provoke and the process of mark making that achieved them, which they feel resonate with the affective qualities of contemporary painting - the painting's stillness, the muted palette with curious colour juxtapositions and very little tonal contrast, the use of wax to make the surface of the painting matt and soft, the nature of depicted light, and, importantly, the sensitive and diffuse quality of the brush strokes. Utley reads the materiality of Potter's painting as articulating a 'direct connection between her observations and her making' (Böse et al. 2016: n.p.) and it is this sense of the artist's touch that allows for this deep connection, painter to painter. 
Nadia Hebson's multifaceted engagement with a close contemporary of Potter's, the British artist Winnifred Knights (1899-47), shares some of the Obscure Secure project's beliefs. Born out of an archival encounter with a photograph of the artist at the British School in Rome when Hebson was herself a scholar there, it has evolved into exhibitions and writings that have developed her creative method of 'subjective biography', a term coined by Hebson to describe her creative interaction with Knight's life and oeuvre. Knights, a much-lauded artist during her lifetime, who has subsequently fallen into relative obscurity (although a recent retrospective at Dulwich Picture Gallery has begun to amend this), presents a model of diverse production (painting, design, clothing, styling) for the contemporary painter who is piecing together her own forebears. Hebson writes,

If those around you are unable to comprehend the breadth of your activities or even to conceive of these as an art practice, the hope remains that new generations will assume the possibility of comprehension for a legacy to reemerge. Artworks endure precisely because we can re-conceive them. Their meanings mutable, contingent. (Hebson, 2016: n.p.)

As a 'woman artist' Hebson states her interest is in what 'happens in the margins...in parallel or dis-associated from acknowledged lineages, hidden from plain sight' ( 2016: n.p.). In recuperating Knights' work, she responds with a sensitivity borne from meticulous scholarship, or what she terms as 'empathy ... as a radical act' (Hebson 2016: n.p.). This conception of painting as a mode of enquiry allows Hebson to carve out a generative methodology of response, where her painting practice gets reimagined, across different forms and moments of publication, as a set of changing and 
poetic relationships between surfaces and objects, images and abstractions, crafted works and prefabricated materials, the contemporary and the historical, settling briefly into transient juxtapositions rather than fixed object commodities. These artists demonstrate, by their dynamic engagement with a recovered art historical legacies, processes that lie, to use Mieke Bal's words, outside 'dogmatically restricted methods...giv[ing] meaning to messages one vaguely senses but can fail to analyse' to make 'a valuable contribution of semiotics to the understanding of art; art, not as a fixed collection of enshrined objects, but as an ongoing live process' (Bal 1996: 40). In doing so, they have developed methods for their own production as women artists, while also shoring up the history of their gender's creativity.

\section{Materiality and meaning}

As Hilary Robinson has pointed out, late modernism's characterization of painting as a repository of feeling, transferred and embedded by the artist in the work's facture, has led to feminist analyses that are more at home discussing image than 'engag[ing] with the materiality of the work' (Robinson 2006: 111). For a generation of women painters the shadow of Abstract Expressionism loomed large over initial attempts to explore painting from a feminist (or indeed any critical) perspective, and discussion of materiality tended to centre on the gestural mark or, what Frederic Jameson calls, the 'distinctive, individual brush stroke' (Manghani 2017: NB reference to article in same issue). Margaret Iversen points out the challenge to the dominance of the gesture as it occurred in the late 1950s and early 1960s and the need to "clear the air of metaphysical cant which surrounded Abstract Expressionism, especially the 
importance attached to the unique individuality of the expressionist gesture' (Iversen 1986: 91). Later, the neo-expressionism of the early 1980s was also to be questioned by artists, particularly women artists, for whom the painterly gesture (neo or otherwise) had come to stand for masculine authorship, the ego-centred, personal trace. A range of strategies was deployed to challenge, eliminate or debase the gesture - the use of fragmentation, repetition or photographic imagery, the referencing of popular culture as well as the mechanization or isolation of certain processes of painting. This could be seen, for example, in the use of 'quotations' in the early work of Fiona Rae that co-opted a debased graphic language for the gestural marks of abstraction. More overt 'no hope of transcendence' (to use John Stezaker's phrase) offerings, traced from a trajectory of 'bad' painting, such as the good 'bad' painting of Lisa Yuksavage, or the bad painting of Stella Vine, could also be seen as a continuation of these responses. However, the easy assimilation of these works into the market, when coupled with very little attention from a feminist perspective, meant that these strategies appeared to leave the painter either erased from her work as an editor of borrowed images or engulfed by the personal, in a solipsistic loop of self reference. British painters such as Thérèse Oulton and Rosa Lee built large, expansive canvases from small, uniform, repeated brush marks, challenging the 'grand wrestle' with material that led to gesture becoming indexically linked to notions of authenticity and authorship, and also, taking a cue from Helen Frankenthaler, pouring or staining were sometimes also positioned in opposition to the gesture. In the early 1990s, the US painter Shirley Kaneda put forward arguments for the valorization of the 'feminine' within painting, which questioned the championing of certain aesthetic qualities to the detriment of others, echoing Lynda Nead's detection of a 'phallocentric textuality' in the discussion of painting's 'handling and style' (Nead 
1992: 58). However, various attempts to make a critical space for the discussion of the materiality of painting within a feminist context during that period in the United Kingdom had only a very localized impact and the notable absence of painting by women connected with that debate in survey shows or museum collections attests that Pollock was more or less correct in her assertion that ' ...the feminine, however much it is locally valorized by women painters and viewers, continues its prescribed role as cipher against which masculinity erects its domination' (Pollock 1992: 151).

Younger painters, such as the American painter Dana Schutz (b. 1976), thus inherited a notion of 'painterliness' as a 'no go' area for an artist wanting to develop a critical practice:

When I first started thinking about contemporary painting in the late 90s there was a feeling that if you were to make something 'painterly' it has to be a quote of what painterliness could represent...I actually enjoy working with material moving it around. But early on, I read essays in undergrad about why you should not make these types of painting....[it was] ethically and politically wrong. (Earnest 2012: n.p.)

However, like many others of her generation, Schutz talks herself round,

But [then] the older arguments about painterly painting didn't seem to make as much sense. Even the avant garde could be seen as a style....I am a feminist and I am thankful for artists who have moved the conversation forward. But my 
experience is different. I mean the 90 s was a great time for women artists. (Earnest 2012: n.p.)

She goes on to cite Judith Linhares, Cecily Brown, Laura Owen, Nicole Eisenman, Karen Kilimnik and Lisa Yuksavage as important role models. Painting practices by women that both explored the materialty of paint yet remained sceptical to the grand claims of the modernist project thus began to emerge in greater numbers. Painter Amy Sillman recounts her undergraduate attitudes to the 'delivery systems' of Abstract Expressionism with a refreshing breeziness, 'AbEx was something grand lying around the dollar bin at the second-hand bookstore, something to be looked at, cut up and used as material' (2011: 252). As a mature artist this approach emerges as a deliberate strategy in her production,

Later on I could perform a more sophisticated maneuver by doubling back on and revering the injunction against AbEx, performing a critique of a critique, one that allowed me to appropriate AbEx as a practice back into my own hands and twist it into the form I wanted it to assume.....This reclamation amounted to reversing the reversal of its fortune. (Sillman 2011: 252)

In this new context feminist critique can be applied retrospectively to practices that initially may have been thought to have little to say to the women's movement. In her essay 'Painting with ambivalence' (that provides the kind of close reading of actual paintings often absent from critical debates), Helen Molesworth recoups the abstract painting of Howardena Pindell, Joan Snyder and Mary Heilmann for a feminist 
context, discussing the strategies such as their 'gendering' of colour or use of the grid. As she explains,

Situated between the vulgarity of Abstract Expressionism and the dialectic of the grid, between the putative failure of painting and the medium's historical dominance, between the potential of feminist liberation and the entrenched nature of patriarchal power, the painting of Heilmann, Pindell and Snyder court notions of failure and abjection, they are rife with ambivalence.

(Molesworth 2007: 438)

As Molesworth suggests, the differentiations and distinctions between these artists' work and the practices by their peers are subtle, and her reading is nuanced. In this field of interpretation and process, strategies are unstable and slippery, with changing implications from practice to practice, even from painting to painting. For example, a certain palette cannot intrinsically be given symbolic meaning, and yet within a particular set of circumstances of place, date and form it can indeed be said to strategically utilize 'bad taste'. Interestingly, all three artists emerge from the moment of a loss of faith in painting as both dominant and critical with a sustained and serious commitment to the medium, which earns them the right - somewhat belatedly and never in full measure - of proper critical engagement. Similarly, Anne Wagner's thrilling account of Lee Krasner's shape shifting, the necessary 'fictions' that allow her to paint, emerges from a close reading of the artist's aesthetic decisions within the context in which they were formed (Wagner 1996: 160). With 'no heritage she could take for granted' and yet positioned at the epicentre of the modern movement by education and peer association, she explores how Krasner adopts a range of 'distinctly 
different' identities within her painting, allowing her to operate at an historical moment when (in Krasner's own words) she is 'a product of this civilization and, you might say that the whole of this civilization and culture is macho' (Wagner 1996: $180)$.

When painting is no longer pre-eminent it appears artists may take it up (often as a medium among others) as a way of exploring both the reproductive and the virtual. For the gestural mark, one of its pleasures, that of its metonymic relation to the painter, which for earlier generations may have been its pitfall, perhaps for the younger (female) artist might assert an active, material, thinking, corporeal self that may be as useful as it is seductive. For younger artists the sense of the trajectory of painting's enquiry, the modern painting project, is perhaps replaced with painting as an encounter with a handmade artefact occasioned by the shift in painting's position in relation to both dominant digital modes of representation and contemporary art's embrace of de-materialized practices. When human interaction is mostly screenbased, constant yet fleeting, and when painting no longer signifies art's apotheosis, the 'coded' nature of the gesture's indexicality becomes more apparent. Within art's current plural economy, feminist critical thinking may be able to usefully reflect on the staging of painting's 'aesthetic conventions concerning style and expressivity' (Doane 2007: 3) in order to understand the materiality of paint and gesture less as the dumb product of self expression, and more as elements that are able to both enact and reflect upon the making and viewing of art, allowing painting to become a space for a manifestation of thought. The 'trace' of painting then does not only bear witness to the lived experience of women, but also mediates a reflective (female) intellectual 
subjectivity, allowing the priorities, complexities and poetics of women a broader audience. Perhaps a model for such an approach can already be found in Wagner's notion of 'painting as autobiography' (in this instance how it offers an 'account of the artist Krasner') as she explores Krasner's handling of gesture and composition through a series of 'delegated' or 'distanced' identities, ultimately revealing her painting to offer "fictions of the self at the very place where truth is "supposed" to be laid bare' (Wagner 1996: 170).

Mira Schor reminds us in her essay, 'Researching visual pleasure', of the filtering that goes on in acts of interpretation and wonders, 'for the future of painting' (Schor [1991] 1996: 159), why aspects of Ad Reinhart's practice, such as his critical collages or his passion for Islamic pattern, have been 'quarantined' from his painting production. The conception of painting as a mode of enquiry that takes different forms (some of which might not be in paint) additionally allows the artist to draw on a range of positions that do not necessarily need to cohere. Indeed, this flexibility in modes of authorship has particular potential for women. Dana Schutz detects a sensibility pertinent to painting in the production of certain female musicians, one that both complicates ideas of expression and utilizes an unstable voice,

I think it's a mistake to think that Expressionism was all about the artist's angst....With these female musicians of the 90s I think angst operated in a unique way. It was... something that oscillated between being both felt and disconnected... gender with these musicians seemed to reverberate back on itself in really twisted ways. It actually felt closer to my experience as a woman. ${ }^{6}$ (Earnest 2012: n.p.) 
Thus, painters who are women are able to riff on the gesture, simultaneously inside and excluded from painting's history. Melissa Gordon (b. 1981) deals with this head on in her 'Mimetic pleasures' series of gestural abstract paintings, where she painstakingly reproduces the random brush marks left as she rids her brush of excess fluid on her studio wall during the painting process, thus, as Eva Kenny points out, debunking masculine authorship while establishing female authority over image and abstraction, simultaneously 'fetishising' and 'mocking' the gesture (Kenny 2014: 2). Her interest in the staging of the viewing experience of painting and the audience's encounter with the surfaces of painting is both coolly analytical of and fervently engaged with painting's history. Cathy Wilke's (b. 1966) introduction of small paintings into her hauntingly strange groupings of figures and objects, displayed at her Tate Liverpool exhibition (2015), also explores painting's unstable status. Although ostensibly secure in painting's material form (paint, brush mark, support), these painted marks on a surface double up as stains left behind on objects, littered among the archaeological debris of domestic life. They appear unloved and discarded and yet simultaneously retrieved and precious, both 'painting' and 'not painting'. Isabella Graw and Daniel Birnbaum describe painter Jutta Koether's (b. 1958) novella $f$ as a

rallying call for painting by someone who is not supposed to paint, written by someone who finds herself fixed in the place of the hysterical woman. What is significant is that this position is adopted and refused at the same time. (Koether [1987] 2015: 6) 
Koether herself seems to see the artist as occupying a multiplicity of positions:

Now she shows how it really is with paintings, how they are produced, and says that her development began with the development of her penmanship....To write an 'I' for the first time and to let it get out of hand right away: spreading out, dispersing, movement, essentially. That's how it all began. (Koether [1987] 2015: 16)

Molesworth's 'ambivalence' and Wagner's 'fictions' thus resurface as a deliberate strategy in the work of contemporary female painters, often with expanded practices, most of whom identify as feminists. Indeed, such ambivalence can be seen as intrinsic to the contemporary painting project; Koether's position is simultaneously 'adopted and refused' and that of Schutz is both 'felt and disconnected', perhaps even reaching beyond Laura Mulvey's 'double identification' towards 'dispersal' (to use Koether's term) or the plurality of 'disidentification'.

In an argument against feminism's absorption into postmodern academic discourse, Amelia Jones makes a case for visual pleasure in relation to 'feminist body art practices' of the 1970s,

...at this particular moment the most radical re-thinking of feminism can take place through the articulation of re-embodied theories of female artistic subjectivity, feminist agency and representation in the broadest sense. Ideally, be re-embodying the subjects of feminism - by saturating theory in and with the desiring making, viewing and interpretative bodies of art theory and practice - 
the notion of a unified feminist subject ....can be rejected. And, by acknowledging multiple feminist subjects of infinitely variable identities, we can perform reinvigorated feminist art histories and practices that are radically empowered through the newly recognised diversity of feminisms. ([1993] 1998: 395)

Written in 1993 it is interesting to note that subsequent to this call these practices have indeed been recouped for both feminist and mainstream audiences. Jones' reasoning fits equally well today as a case for a feminist re-appraisal of contemporary painting. Such a discourse will need to come to terms with a plurality of feminisms and subjectivities, and the particular forms of contradiction and ambivalence painting supports. And for painting's histories, which continue to be written without women's contribution being fully recognized, this work is most urgent.

\section{References}

Bal, M. (1996), 'Reading art?', in G. Pollock (ed.), Generations and Geographies in the Visual Arts: Feminist Readings, London and New York: Routledge, pp. 25-41.

Betterton, R. (2004), Unframed, the Practices and Politics of Women's Contemporary Painting, London and New York: I B Tauris.

Bloom, H. ([1973] 1997), The Anxiety of Influence, A Theory of Poetry, London and Oxford: Oxford University Press. 
Böse, C. (2014), 'Obscure secure', http://resideresidency.weebly.com/reside-blogclaudia-boumlse/archives/07-2014. Accessed 28 August 2016.

Böse, C., Field, H. and Utley, J. (2015), Obscure Secure Reportf or Arts Council, https://obscuresecureproject.wordpress.com/texts/ Accessed 8 January 2017 (2016), Obscure Secure unpublished notes.

Bui, P. (2010), 'In conversation: Vija Celmins with Phong Bui', Brooklyn Rail, 3 June, http://www.brooklynrail.org/2010/06/art/vija-celmins-with-phong-bui. Accessed 28 August 2016.

Chicago, J. ([1975] 2006), Through the Flower; My Struggle as a Woman Artist, Lincoln: Authors Choice Press.

Cooke R. (2012), 'Jenny Saville: "I want to be a painter of modern life, and modern bodies", The Observer, 9 June, http://www.theguardian.com/artanddesign/2012/jun/09/jenny-saville-painter-modernbodies. Accessed 28 August 2016.

Doane, M. A. (2007), ‘Indexicality: trace and sign; introduction’, Differences: A Journal of Feminist Culural Studies, 18:1, pp. 1-6. 
Earnest, J. (2012), 'Dana Schutz with Jarrett Earnest', The Brooklyn Rail, 4 June, http://www.brooklynrail.org/2012/06/art/dana-schutz-with-jarrett-earnest. Accessed 28 August 2016.

Elwes, C. (1996), 'Video history: Who needs it?', Art Monthly, no. 196, May, http://www.artmonthly.co.uk/magazine/site/article/videoscan-by-catherine-elwesmay-1996. Accessed 28 August 2016.

Hanisch, C. (1969), 'The personal is political', http://www .carolhanisch.org/CHwritings/PIP.html. Accessed 28 August 2016.

Hawkey, C. (2007), 'Mamma Andersson', Bomb, no. 100, Summer 2007. http://bombmagazine.org/article/2905/mamma-andersson. Accessed 28 August 2016.

Hebson, N. (2016), 'Invisible/visible', British Art Studies, 2016: 2 (Spring), Still Visible?, http://www.britishartstudies.ac.uk/issues/issue-index/issue-2/still-invisible. Accessed 28 August 2016.

Iversen, M. (1986), 'Saussure v. Pierce: Models for a semiotics of visual art', in F. Borzello and A. L. Rees (eds), The New Art History, London: Camden Press, pp. 8294.

Jones, A ([1993] 1998), 'Post feminism, feminist pleasures and embodied theories of art', in D. Presiosi (ed.), The Art of Art History: A Critical Anthology, New York: Harper Collins, pp. 383-96. 
Joselit, D. (2015), 'Reassembling painting', in M. Ammer, A. Hochorfer and D. Joselit (eds), Painting 2.0 Expression in the Information Age, Munich, London and New York: DelMonico Books, pp. 169-81.

Kenny, E. (2014), 'Painting behind itself' essay published on poster to accompany

'Melissa Gordon: Mimetic pleasures', solo exhibition at Marianne Boesky Gallery, New York, 10 October-9 November.

Kimmelman, M. (2001), 'In the studio with: Sue Williams; In a Cheerful Groove, With a Plan and Serendipity', New York Times, 28 December, http://www.nytimes.com/2001/12/28/arts/in-the-studio-with-sue-williams-in-acheerful-groove-with-a-plan-and-serendipity.html?pagewanted=all. Accessed 28 August 2016.

Koether, J. ([1987] 2015), f, Berlin: Sternberg Press.

Lloyd, F (2000), 'Painting', in F. Carson and C. Pajaczkowska (eds), Feminist Visual Culture, Edinburgh: Edinburgh University Press, pp. 37-54.

Manghani, S. (2017), 'Painting as commitment', Journal of Contemporary Painting, 3: $1 / 2, \mathrm{pp}$. NB reference to article in same issue 
Molesworth, H. (2007), 'Painting with ambivalence', in L. Gabrielle Mark (ed.), WACK! Art and the Feminist Revolution, Cambridge and London: MIT Press, pp. 428-39.

Moss, A. (2011), 'What we talk about when we talk about painting', LABOUR Magazine, 2011:1 http://whypublish.wikispaces.com/file/view/Gordon,+MelissaVishmidt+Marina-labour.pdf. Accessed 28 August 2016.

Nead, L. (1992), The Female Nude, Art, Obscenity and Sexuality, New York and London: Routledge.

Nochlin, L. (2002), 'A rage to paint', in J. Livingston (ed.), The Paintings of Joan Mitchell, New York and London: The Whitney Museum of American Art in association the University of California Press, pp. 49-59.

Pollock, G. (1992), 'Painting, feminism, history', in M. Barrett and A. Phillips (eds), Destablising Theory, Contemporary Feminist Debates, Stanford California: University of Stanford Press, pp. 138-76.

Robinson, H. (2006), Reading Art, Reading Irigaray: The Politics of Art by Women, London and New York: I B Tauris.

Sauzeau-Boetti, A. M. ([1979] 2015), 'Negative capability as practice in women's art', in H. Robinson (ed.), Feminism-Art-Theory: An Anthology 1968-2014, London: Wiley Blackwell, pp. 220-32. 
Schor, M. (ed.) ([1991] 1996), 'Researching visual pleasure', in Wet: On Painting,

Feminism and Art Culture, Durham and London: Duke University Press, pp. 156-64.

Sillman, A. ([2011] 2015), 'AbEx and Disco Balls: In defense of Abstract

Expressionism II', in H. Robinson (ed.), Feminism-Art-Theory: An Anthology 19682014, London: Wiley Blackwell, pp. 250-54.

Spalding, F. (2014), 'Obscure Secure leaflet for Christchurch Mansions', https://obscuresecureproject.files.wordpress.com/2014/08/os-booklet-design-aw.pdf. Accessed 28 August 2016.

Tate, S. (2013), ‘A motivated history', PERSONA Magazine, 2013: 2, Archive Books pp. 85-91.

Wagner, A. M. (ed.) (1996), 'Krasner's fictions', in Three Artists (Three Women); Modernism and the Art of Hesse, Krasner and O'Keeffe, Berkeley, Los Angeles and London: University of California Press pp. 105-90.

\section{Contributor details}

Rebecca Fortnum is an artist and academic. In 2009 she became Reader of Fine Art at University of the Arts London and was subsequently appointed Professor of Fine Art at Middlesex University, London, in 2013. In 2016 she became Professor of Fine Art 
at the Royal College where she is Senior Tutor in Fine Art Research. Fortnum has received awards from organizations including Pollock-Krasner Foundation, British Council, Arts Council of England, British School in Rome and AHRC. Fortnum was instrumental in founding the artist-run spaces Cubitt and Gasworks, both in London, and is Founding Editor of the Journal of Contemporary Painting. Her books include Contemporary British Women Artists, published by IB Tauris, and On Not Knowing; How Artists Think, which she edited with Lizzie Fisher, published by Black Dog. Recent solo exhibitions include Absurd Impositions at the V\&A's Museum of Childhood (2011) and Self Contained at the Freud Museum with an accompanying book published by RGAP (2013).

Contact:

Royal College of Art, Kensington Gore, London SW7 2EU, UK.

E-mail: rebecca.fortnum@rca.ac.uk

Notes

${ }^{1}$ For example, the East London Fawcett Group Art Audit from 2011
http://eastlondonfawcett.org.uk/art-audit.html or the Guerilla Girls' continuing
campaigns http://www.guerrillagirls.com.

${ }^{2}$ For example, in the United Kingdom, only a quarter of the exhibitors in the Hayward's 'Painting of Modern Life' (2007) were female, and more recently the painting exhibition 'The Show is Over' (Gagosian Gallery London, 2014) exhibited works by 34 male painters and one female, a fact that went for the most part without 
comment in the press attention, while Tate St Ives' 'Indiscipline of Painting' (2014) included just about 25 per cent women.

${ }^{3}$ This year in the United Kingdom, in grassroots artist-led projects like

'Contemporary British Painting' or the 'Marmite Prize for Painting', over half of the exhibitors are women.

${ }^{4}$ I must acknowledge complex and insightful feminist writing on painting; in the United Kingdom this includes Hilary Robinson on Riley and Saville, Griselda Pollock on Ettinger, Alison Rowley on Frankenthaler and Saville, and Rosemary Betterton on Susan Hiller and others.

${ }^{5}$ The Bechdel test, most often applied to the film industry, asks whether a work of fiction features at least two women who talk to each other about something other than a man.

${ }^{6}$ The example Schutz gives is Kim Gordon. 